\title{
EVALUASI KUALITAS LINGKUNGAN PERAIRAN PESISIR DI SEKITAR TPA TELAGA PUNGGUR KOTA BATAM BERDASARKAN STRUKTUR KOMUNITAS MAKROZOOBENTHOS
}

\section{COASTAL AREA QUALITY EVALUATION SURROUND TELAGA PUNGGUR WASTE LANDFILL AREA BASED ON MACROZOOBENTHOS COMMUNITY STRUCTURE}

\author{
Roza Efriningsih ${ }^{1}$, Lani Puspita ${ }^{2 *}$ dan Ramses ${ }^{3}$ \\ ${ }^{123}$ Program Studi Pendidikan Biologi, FKIP, Universitas Riau Kepulauan , Batam \\ *Korespondensi: puspita.lani@gmail.com
}

\begin{abstract}
ABSTRAK
Tempat Pengolahan Akhir (TPA) Sampah Telaga Punggur adalah TPA yang berlokasi di Kota Batam dengan luas lahan $47 \mathrm{Ha}$, lokasinya berbatasan langsung dengan perairan pesisir. Setiap harinya 700800 ton volume sampah diterima TPA dan dihasilkan 25-30 ton air lindi. Aktivitas di TPA Telaga Punggur tersebut (bersama dengan aktivitas-aktivitas lain di daerah Punggur) menimbulkan dampak terhadap penurunan kualitas lingkungan di perairan pesisir sekitarnya. Tujuan penelitian ini adalah mengevaluasi kualitas lingkungan perairan pesisir sekitar TPA Punggur dilihat dari struktur komunitas makrozoobenthos. Penelitian ini dilaksanakan pada bulan April - Mei 2013. Dalam penelitian ini ditetapkan 2 stasiun sampling yang masing-masing terdiri dari 4 plot sampling. Stasiun I di perairan yang berbatasan langsung dengan TPA Telaga Punggur dan Stasiun II berjarak $1 \mathrm{~km}$ dari Stasiun I. Untuk melihat perbedaan antara Stasiun I dan Stasiun II digunakan Uji T dan Uji Man-Whitney. Dari hasil penelitian didapatkan data bahwa ada 11 jenis makrozoobenthos di Stasiun I dan 18 jenis makrozoobenthos di Stasiun II. Secara umum Stasiun I didominasi oleh Kelas Olygochaeta yang bersidat toleran, sedangkan Stasiun II didominasi oleh Kelas Gastropoda yang bersifat fakultatif. Indeks keanekaragaman antara Stasiun I dan II nilainya tidak jauh berbeda, dimana nilai indeks berkategori sedang, yang artinya kondisi perairan tercemar ringan. Berdasarkan analisis Kurva ABC didapatkan bahwa kondisi perairan di Stasiun I dan Stasiun II tidak terganggu. Secara umum kualitas air di Stasiun I dan II tidak jauh berbeda, dimana parameter $\mathrm{pH}$, salinitas, TSS, dan suhu masing sesuai dengan baku mutu untuk biota laut pada ekosistem mangrove, namun kandungan DO rendah. Nilai DO yang rendah menunjukan banyaknya bahan organik pada masing-masing stasiun.
\end{abstract}

Kata kunci: kualitas lingkungan, makrozoobenthos, TPA Telaga Punggur Batam

\begin{abstract}
Telaga Punggur dumpsite is a TPA located in Batam City in 47 ha area, its location is directly adjacent to coastal waters. Every day, 700-800 tons of waste arrives at this dumpsite and produced 25-30 tons of leachate. The activities at Telaga Punggur dumpsite (along with other activities at Punggur area) have an impact on the environmental degradation at its surrounding coastal. The purpose of this study is to evaluate the environmental quality of the surrounding coastal at Telaga Punggur dumpsite viewed by the macrozoobenthos community structure. This research was conducted in April - May 2013. In this research, there are 2 sampling stations consisting of 4 sampling plots. Station I in the waters directly adjacent to Telaga Punggur dumpsite and Station II is $1 \mathrm{~km}$ from Station I. To see the difference between Station I and Station II use Test T and Man-Whitney Test. From the research results obtained data that there are 11 types of macrozoobenthos in Station I and 18 types of macrozoobenthos in Station II. Generally Station I is dominated by tolerant Olygochaeta Class, while Station II is dominated by facultative Gastropoda Class. The index of diversity between Station I and II is slight different, where the index value is moderate, which means that the waters condition is contaminated lightly. Based on the analysis of ABC curve it was found that the water conditions in Station I and Station II were not disturbed. Generally, water quality in Station I and II
\end{abstract}


was slight different, where the parameters of pH, salinity, TSS, and temperature were in accordance with the quality standards for marine biota in mangrove ecosystem, but it was low content of DO . Low content of DO values indicated the huge of amount of organic at each station.

Keywords; Environmenta Quality, macrozoobenthos, Telaga Punggur dumpsite

\section{PENDAHULUAN}

Pesisir Punggur Kota Batam merupakan salah satu wilayah yang telah banyak dikonversi lahannya menjadi kawasan permukiman, pembangkit tenaga listrik, pelabuhan, dan TPA sampah. TPA Sampah Telaga Punggur telah beroperasi sejak 1997 dengan luas sekitar 47 Ha. TPA Sampah ini sebetulnya direncanakan sebagai TPA dengan sistem control landfill, namun kenyataan di lapangan yang berjalan adalah sistem open dumping. Setiap harinya 700-800 ton sampah diterima TPA Punggur dan pada TPA ini dihasilkan 25-30 ton air lindi/hari. Aktivitas-aktivitas di daerah Punggur ini akan memberikan tekanan terhadap lingkungan. Tekanan terhadap lingkungan tersebut antara lain akan mempengaruhi struktur komunitas biota perairan. Salah satu biota yang dapat digunakan sebagai bioindikator kualitas lingkungan di perairan adalah makrozoobenthos.

Penelitian ini bertujuan untuk: (1) Menganalisis struktur komunitas makrozoobenthos melalui perhitungan komposisi dan kepadatan jenis, indeks keanekaragaman jenis $\left(H^{\prime}\right)$, indeks keseragaman jenis (E), serta indeks dominansi jenis (D); (2) Mengkaji kualitas lingkungan perairan melalui penggunaan Kurva Abundance Biomass Comparison (ABC); dan (3) Mengkaji kualitas lingkungan berdasarkan faktor fisika dan kimia lingkungan perairan serta akumulasi loga pada hewan Gastropoda. Hasil penelitian ini diharapkan dapat memberikan informasi tentang gambaran kondisi perairan di sekitar TPA Telaga Punggur dengan menggunakan bioindikator.

\section{METODE PENELITIAN}

Penelitian ini dilaksanakan pada bulan April - Mei 2013 di perairan pesisir sekitar TPA Telaga Punggur Kecamatan Nongsa Kota Batam Provinsi Kepulauan Riau. Penentuan stasiun sampling dilakukan dengan metode purposive sampling berdasarkan jarak lokasi sampling dari TPA Telaga Punggur (yang diasumsikan sebagai sumber pencemar). Stasiun I berlokasi di perairan pesisir yang berbatasan langsung dengan TPA Telaga Punggur, dan 
Stasiun II adalah di daerah pesisir Teluk Lengung yang berjarak $1 \mathrm{~km}$ dari TPA. Pada masing-masing stasiun penelitian dibuat 4 plot pengamatan.

Koordinat plot sampling di Stasiun I (TPA Telaga Punggur) adalah sbb:

Plot 1 : N $1.05006^{\circ}$ E $104.12000^{\circ}$

Plot 2 : N $1.05003^{\circ} \quad$ E $104.12001^{\circ}$

Plot 3 : N $1.04969^{\circ} \quad$ E $104.11961^{\circ}$

Plot 4 : N $1.04943^{\circ} \quad$ E $104.11924^{\circ}$

Koordinat plot sampling di Stasiun II (Teluk Lengung) adalah sbb:

Plot 1 : N $1.04132^{\circ}$ E $104.11803^{\circ}$

Plot $2: \mathrm{N} 1.04212^{\circ}$ E $104.11827^{\circ}$

Plot $3: \mathrm{N} 1.04052^{\circ} \quad$ E $104.11792^{\circ}$

Plot $4: \mathrm{N} 1.03844^{\circ}$ E $104.11791^{\circ}$

\section{Metode Pengambilan Sampel}

Pengambilan contoh makrozoobenthos diambil pada setiap plot pengamatan $1 \mathrm{x} 1$ $\mathrm{m}$, makrozoobenthos diambil secara acak pada plot $1 \mathrm{x} 1 \mathrm{~m}$ tersebut menggunakan paralon berdiameter 2 inci sebanyak 15 - 20 ulangan. Pemisahan makrozoobenthos dengan substrat dilakukan di lapagan menggunakan saringan benthos bertingkat dengan mata saring terakhir berukuran $1 \times 1 \mathrm{~mm}$. Makrozoobenthos yang tersaring kemudian diawetkan dalam larutan formali $4 \%$ dan diidentifikasi di laboratorium. Identifikasi dilakukan menggunakan buku Tropical Seashell (Fiene-Severns et. al, 2000), Shells (Sabelli, 1991), dan Avertebrata Air (Suwignyo et. al, 2005). Setelah identifikasi, selanjutnya dilakukan perhitungan jumlah makrozoobenthos berdasarkan jenis. Untuk memperoleh data berat kering, makrozoobenthos dipanaskan di-oven selama \pm 3 jam.

Analisis karakteristik fisika dan kimia perairan dilakukan secara insitu (untuk suhu, DO, $\mathrm{pH}$, dan salinitas) dan di laboratorium (untuk parameter TSS, minyak dan lemak, raksa, kromium, arsen, kadmium, timbal, tembaga, dan seng). Untuk analisis di laboratorium digunakan jasa pihak ketiga, yaitu Laboratorium Produktivitas Lingkungan (Proling) Perairan Institut Pertanian Bogor (IPB). 


\section{Alat dan Bahan}

Peralatan yang digunakan di lapangan adalah: Global Positioning System (GPS), plastik bening, kamera digital, sampan, saringan benthos, loop, pinset, paralon berdiameter 2 inci, transek $1 \times 1 \mathrm{~m}$, botol sampling, saringan benthos, DO meter, $\mathrm{pH}$ meter, dan refraktometer. Peralatan yang digunakan di laboratorium adalah: oven dan timbangan. Bahan-bahan yang digunakan adalah aquades, asam nitrat, dan larutan formalin $4 \%$.

\section{Metode Analisis Data}

\section{Analisis Struktur Komunitas Makrozoobenthos}

$\underline{\text { Keanekaragaman Jenis }}$

Tingkat keanekaragaman jenis menggambarkan banyaknya jumlah jenis dan proporsi kelimpahan individu antar jenis suatu makhluk hidup pada suatu komunitas. Keanekaragaman jenis dihitung dengan menghitung Indeks Keanekaragaman Jenis Shannon - Wienner (H'). Rumusnya adalah sebagai berikut (Odum, 1998):

$$
H^{\prime}=\sum\left(\frac{N_{i}}{N_{\text {total }}} \bullet \log _{2} \frac{N_{i}}{N_{\text {total }}}\right)
$$

$\mathrm{H}^{\prime} \quad=$ Indeks Keanekaragaman Jenis Shannon - Wienner

$\mathrm{N}_{\mathrm{i}} \quad=$ jumlah individu makrozoobenthos jenis ke-i (individu)

$\mathrm{N}_{\text {total }}=$ jumlah seluruh jenis udang di satu stasiun sampling (individu)

$\log _{2}=$ logaritma basis dua

Kisaran nilai:

$0 \leq \mathrm{H}^{\prime}<1 \quad$ tingkat keanekaragaman jenis rendah

$1 \leq \mathrm{H}^{\prime}<3 \quad$ tingkat keanekaragaman jenis sedang

$\mathrm{H}^{\prime} \geq 3 \quad$ tingkat keanekaragaman jenis tinggi

$\underline{\text { Keseragaman Jenis }}$

Tingkat keseragaman jenis menggambarkan keseragaman jumlah populasi antar jenis suatu makhluk hidup pada suatu komunitas. Keseragaman jenis dihitung dengan menghitung Indeks Keseragaman Jenis Evenness (E). Rumusnya adalah sebagai berikut (Odum, 1998):

$$
E=\frac{H^{\prime}}{\log _{2} S}
$$

$\mathrm{E} \quad=$ Indeks Keseragaman Evenness

$\mathrm{H}^{\prime} \quad=$ Indeks keanekaragaman Shannon - Wienner

$\log _{2}=$ logaritma basis 2

$\mathrm{S} \quad=$ jumlah jenis makrozoobenthos yang ditemukan 
Kisaran nilai:

$0 \leq \mathrm{E}<0,3 \quad$ tingkat keseragaman jenis rendah

$0,3 \leq \mathrm{E}<0,6$ tingkat keseragaman jenis sedang

$0,6 \leq \mathrm{E}<1,0$ tingkat keseragaman jenis tinggi

\section{Dominansi Jenis}

Tingkat dominansi jenis menggambarkan ada tidaknya salah satu atau beberapa jenis makhluk hidup yang jumlah populasinya dominan sehingga mendominasi jenis yang lainnya pada suatu komunitas. Dominansi jenis dihitung dengan menghitung Indeks Dominansi Simpson. Rumusnya adalah sebagai berikut (Odum, 1998):

$$
D=\sum\left(\frac{N_{i}}{N_{\text {total }}}\right)^{2}
$$

$\mathrm{D}=$ indeks dominansi simpson

$\mathrm{N}_{\mathrm{i}} \quad=$ jumlah individu makrozoobenthos jenis ke-i (individu)

$\mathrm{N}_{\text {total }}=$ jumlah seluruh jenis mosakrozoobenth di satu stasiun sampling (individu)

Kisaran nilai:

$0 \leq \mathrm{D}<0,3 \quad$ tingkat dominansi jenis rendah

$0,3 \leq \mathrm{D}<0,6$ tingkat dominansi jenis sedang

$0,6 \leq \mathrm{E}<1,0$ tingkat dominansi jenis tinggi

\section{Analisis Kurva ABC (Abundance Biomass Comparison)}

Metode ini digunakan untuk mengetahui kondisi lingkungan dengan menganalisis jumlah total individu per satuan luas dan biomassa (berat kering) total per satuan luas (Warwick, 1986). Langkah pembuatan Kurva ABC adalah sebagai berikut:

1. Buat daftar persentase relatif jumlah total individu per satuan luas dan biomassa per satuan luas dari masing-masing jenis makrozoobenthos.

2. Menyusun rangking masing-masing jenis berdasarkan persentase relatif jumlah total individu dan biomassa per satuan luas dan selanjutnya membuat kumulatif dominan dari persentase relatif.

3. Memplotkan data rangking jumlah total individu per satuan luas dan biomassa per satuan luas pada Sumbu X dan memplotkan data persentase kumulatif dominan dari jumlah invidivu per satuan luas dan berat per satuan luas pada Sumbu Y. 


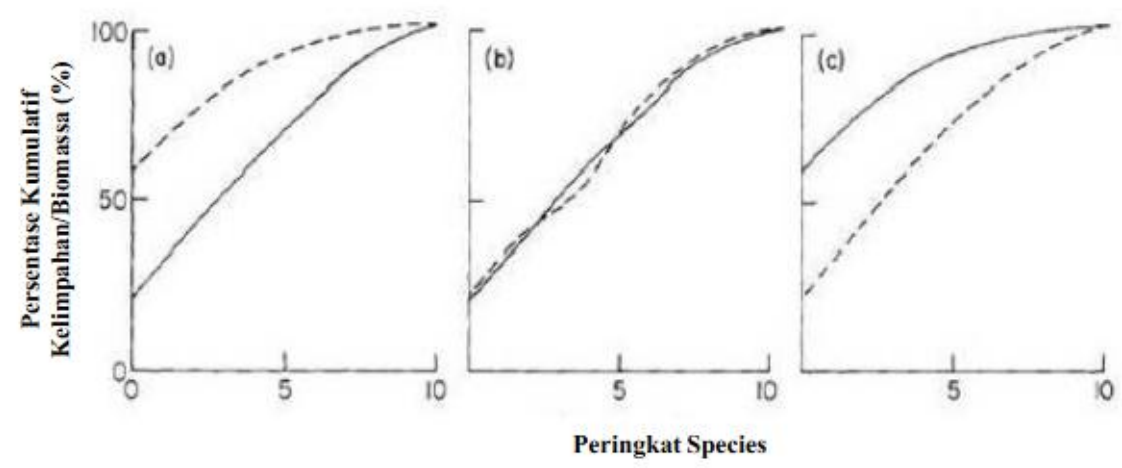

Gambar 1. Contoh Kurva ABC pada Berbagai Kondisi Perairan Keterangan:

(_ $)$ : kelimpahan spesies

(--------) : biomassa

(a) : kondisi ekosistem tidak terganggu (tidak tercemar)

(b) : terganggu intensitas sedang/moderat (agak tercemar)

(c) : kondisi adanya gangguan dan tekanan ekologi (tercemar)

\section{Analisis Data secara Statistik Inferensial}

Analisis data secara statistik inferensial dilakukan untuk melihat apakah ada perbedaan signifikan antara kedua stasiun sampling. Uji yang digunakan adalah Uji t dan Uji Mann Whitney. Uji t digunakan apabila data terdistribusi normal, sedangkan Uji Mann Whitney digunakan apabila data tidak terdistribusi normal. Analisis data dilakukan dengan bantuan aplikasi Minitab 14.

\section{HASIL DAN PEMBAHASAN}

\section{Komposisi dan Kepadatan Makrozoobenthos}

Dari hasil pengamatan pada keempat plot di Stasiun I ditemukan 11 jenis makrozoobenthos, yaitu: 5 jenis dari Kelas Gastropoda (Telescopium telescopium, Cerithium cingulata, Cerithium zonatum, Assiminea brevicula, dan Assiminea sp.), 2 jenis dari Kelas Polychaeta (Famili Tubificidae dan Lumbricullidae), 2 jenis dari Kelas Olygochaeta (Famili Nephtydae dan Nereidae), 1 jenis dari Filum Uniramia/Insekta (Famili Polycentropodidae), dan 1 jenis dari Filum Crustacea (Famili Gammaridae). Pada masing-masing plot dijumpai $8-9$ jenis makrozoobenthos. Jumlah jenis terbanyak ditemukan pada Plot 1 dan 3, sedangkan jumlah jenis paling sedikit ditemukan pada Plot 4 . 
Komposisi dan kepadatan jenis makrozoobenthos yang ditemukan pada Stasiun I dari masing-masing plot disajikan pada Gambar 1.

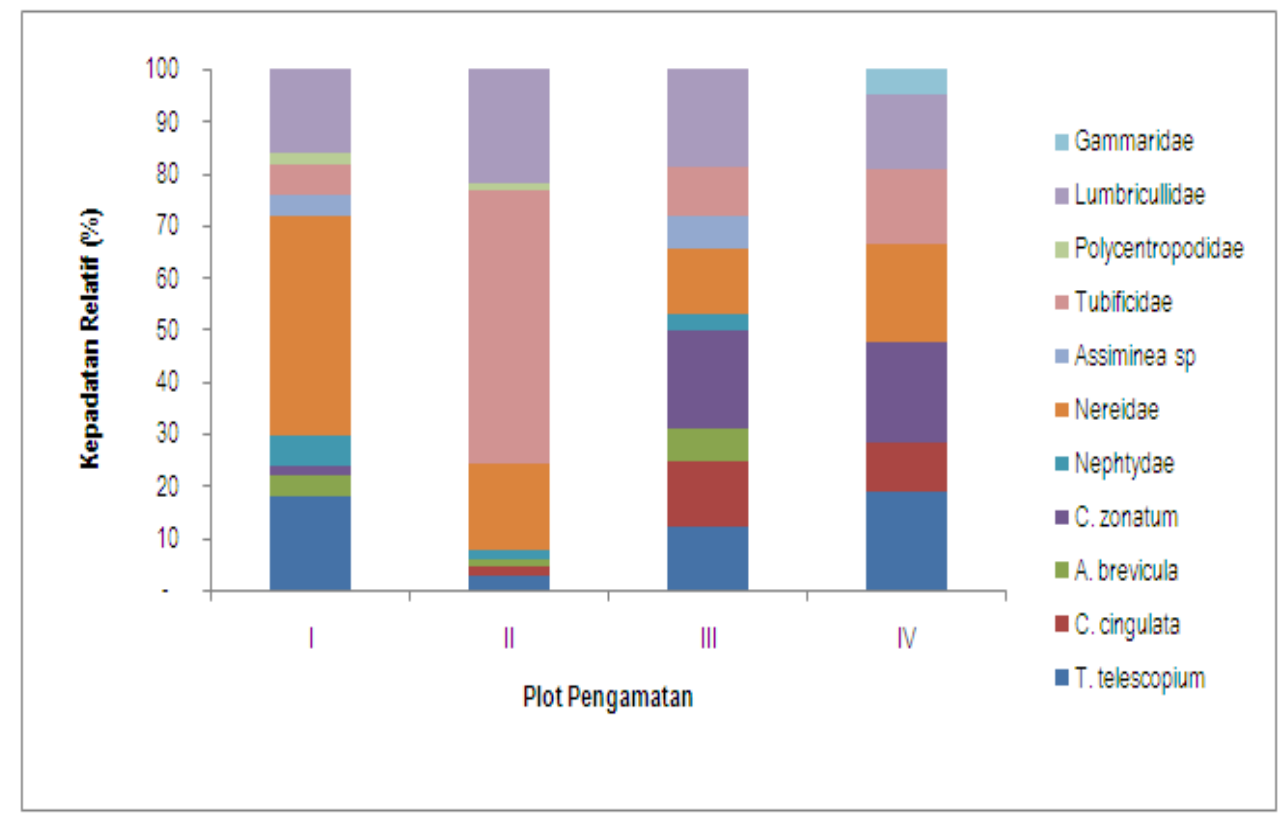

Gambar 1. Komposisi dan Kepadatan Relatif Makrozoobenthos pada Setiap Plot Pengamatan di Stasiun 1

Pada Stasiun II, jenis makrozoobenthos yang ditemukan lebih banyak dibandingkan di Stasiun I. Pada Stasiun II ditemukan 18 jenis makrozoobenthos, yaitu: 11 jenis dari Kelas Gastropoda (Cerithium zonatum, Chicoreus capunicus, Assiminea brevicula, Terebralia sulcata, Cerithium obtuse, Cerithium cingulata, Nerita lineate, Macron rapallum, Littoraria scabra, Littorina aspersa, dan Nerita undata), 3 jenis dari Kelas Polychaeta (Nereis sp., Nereidae, dan Nephtydae), 2 jenis dari Kelas Bivalvia (Anadara granosa dan Batissa violacea), 1 jenis dari Kelas Olygochaeta (Lumbricullidae), dan 1 jenis dari Filum Sipuncula (Golfingia vulgaris). Jumlah jenis yang ditemukan pada masing-masing plot adalah $7-8$ jenis. Frekuensi kemunculan jenis dari masing-masing plot berbeda-beda, hanya Terebralia sulcata yang muncul pada setiap plot pengamatan. Terjadinya perbedaan frekuensi kemunculan jenis makrozoobenthos pada masing-masing plot disebabkan oleh kondisi lingkungan yang berbeda, yaitu jenis substrat dan kerapatan tumbuhan mangrove. Komposisi dan kepadatan jenis makrozoobenthos yang ditemukan pada Stasiun II dari masing-masing plot disajikan pada Gambar 2. 


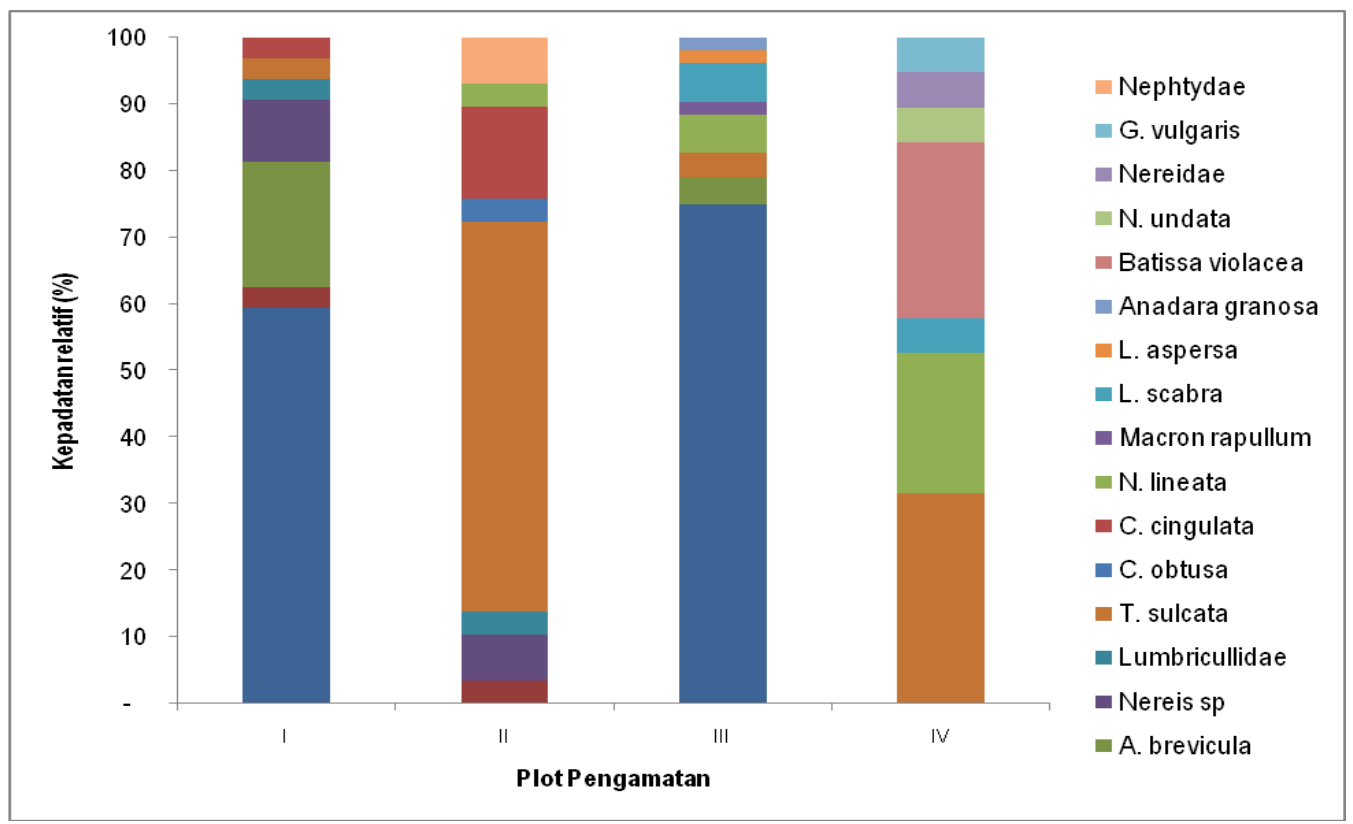

Gambar 2. Komposisi dan Kepadatan Relatif Makrozoobenthos pada Setiap Plot Pengamatan di Stasiun 2

Pada Gambar 3 disajikan komposisi dan kepadatan jenis makrozoobenthos di Stasiun I dan II untuk setiap filum/kelasnya. Makrozoobenthos yang ditemukan di Stasiun I tergolong dalam 5 kelas, yaitu: Gastropoda, Olygochaeta, Polychaeta, Insecta, dan Crustacea. Pada Gambar 3 tersebut dapat dilihat bahwa 44\% jenis makrozoobenthos di Stasiun I tergolong pada Kelas Olygochaeta, sebanyak 27.4\% tergolong ke dalam Kelas Gastropoda, sebanyak 26.8\% tergolong ke dalam kelas Polychaeta, sebanyak $1.2 \%$ tergolong ke dalam Filum Uniramia/Insecta, dan sebanyak 0.6\% tergolong ke dalam Filum Crustacea.

Kelas yang paling banyak dijumpai di Stasiun I adalah Olygochaeta (44\%). Olygochaeta yang ditemukan di Stasiun I didominasi oleh Famili Tubificidae. Melimpahnya Tubificidae diduga disebabkan karena banyaknya nutrisi dari bahan-bahan organik yang salah satunya bersumber dari buangan pengolahan air lindi TPA Telaga Punggur. Menurut Barus (1996), Famili Tubificidae mempunyai tingkat toleransi yang tinggi terhadap pencemar (khususnya pencemaran bahan organik). Substrat di Stasiun I cenderung didominasi oleh substrat berlumpur, hal ini juga diduga mempengaruhi kelimpahan jenis dari Famili Tubificidae.

Di Stasiun I, Polychaeta juga memiliki kepadatan relatif yang tinggi (26.8\%). Polychaeta tersebut terdiri dari Famili Nereidae. Menurut Lardicci dan Castelli (1985) 
dalam Setiawan (2007), jenis Nereis sp. dari Famili Nereidae memiliki kemampuan menyerap bahan organik terlarut, mampu beradaptasi terhadap perubahan salinitas, serta toleran terhadap kandungan oksigen rendah, konsentrasi logam berat yang cukup tinggi, dan perubahan suhu yang ekstrim.

Berbeda dengan di Stasiun I, pada Stasiun II kepadatan relatif dari Kelas Polychaeta dan Olygochaeta tergolong rendah. Pada Gambar 3 dapat dilihat bahwa kelas yang mendominasi adalah Kelas Gastropoda $(87,1 \%)$; kondisi tersebut diduga karena kualitas perairan di Stasiun II lebih baik dibandingka Stasiun I. Menurut Barnes (1999), Kelas Gastropoda mempunyai anggota terbanyak dan memiliki habitat yang bervariasi. Menurut Jailani dan Nur (2002), Kelas Gastropoda termasuk hewan kelompok fakultatif, yaitu hewan yang mampu hidup dalam kisaran kondisi lingkungan yang lebih luas dibandingkan dari yang bersifat intoleran. Selanjutnya menurut Fachrul (2007), makrozoobenthos yang bersifat fakultatif dapat bertahan hidup pada lingkungan perairan belum tercemar hingga tercemar sedang.

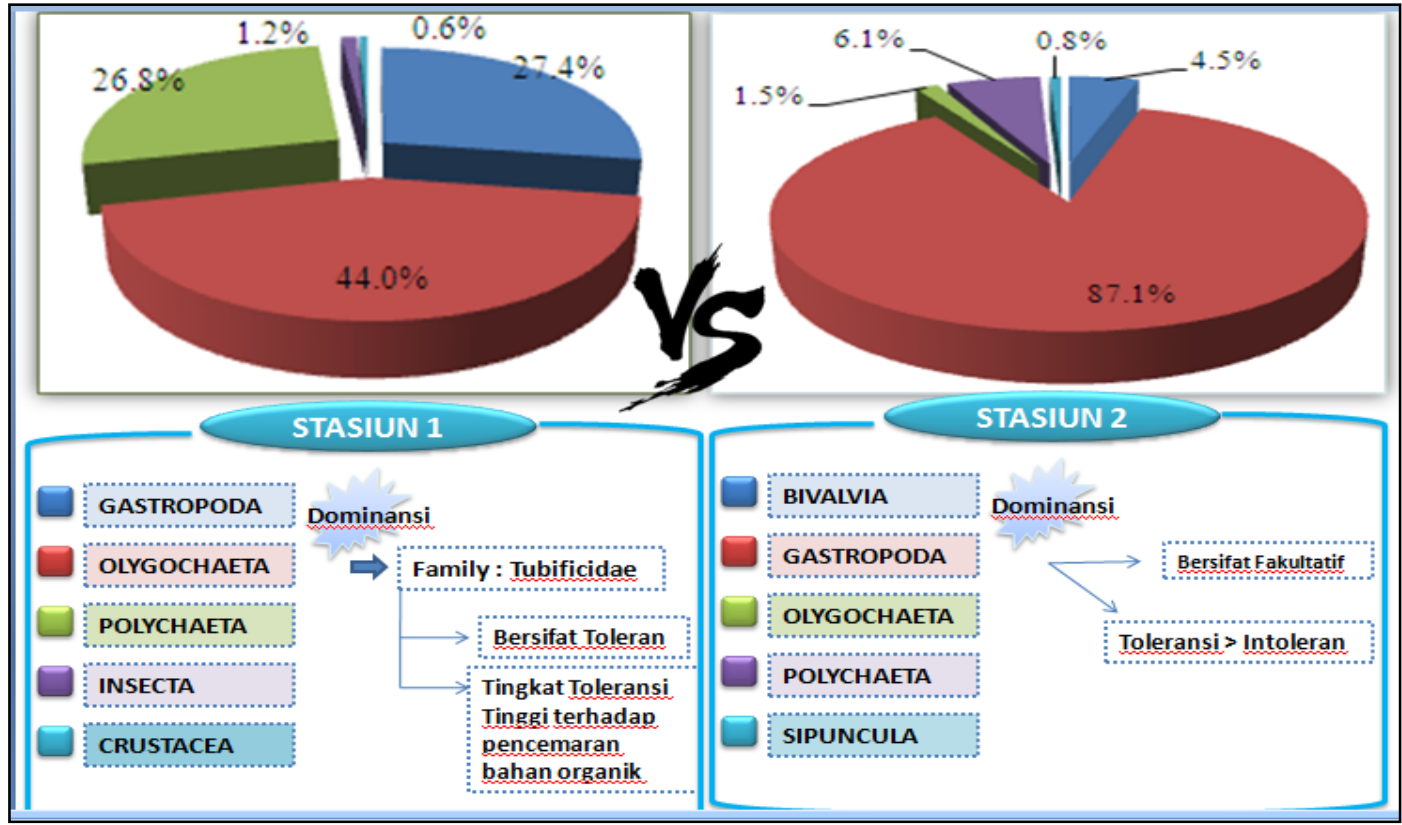

Gambar 3. Komposisi dan Kepadatan Jenis Makrozoobenthos di Stasiun I dan II Berdasarkan Kelasnya

\section{Indeks Keanekaragaman, Keseragaman, dan Dominans}

Pada Gambar 4 disajikan perbandingan nilai Indeks Keanekaragaman (H'), Indeks Keseragaman (E), dan Indeks Dominansi (D) antara Stasiun I dan II. Pada Gambar tersebut dapat dilihat bahwa nilai Indeks H' antara Stasiun I dan II tidak terlalu jauh berbeda, yaitu 
berada pada kategori sedang yang menunjukkan bahwa kualitas perairan tercemar ringan. Menurut Fitriana (2006), kondisi tersebut menunjukkan bahwa produktivitas cukup tinggi, kondisi ekosistem seimbang, dan tekanan ekologi sedang.

Nilai Indeks E pada Stasiun I dan II lebih besar dari 0.6, hal tersebut menunjukkan bahwa kedua stasiun tersebut memiliki keseragaman jenis yang tinggi. Hal ini secara umum menunjukkan bahwa di setiap stasiun tidak ada dominansi jenis. Tingginya nilai Indeks Keseragaman umumnya selalu diikuti dengan nilai Indeks Dominansi yang rendah, hal tersebut dapat dilihat dari nilai Indeks Dominansi di kedua stasiun yang lebih kecil dari 0.3 .

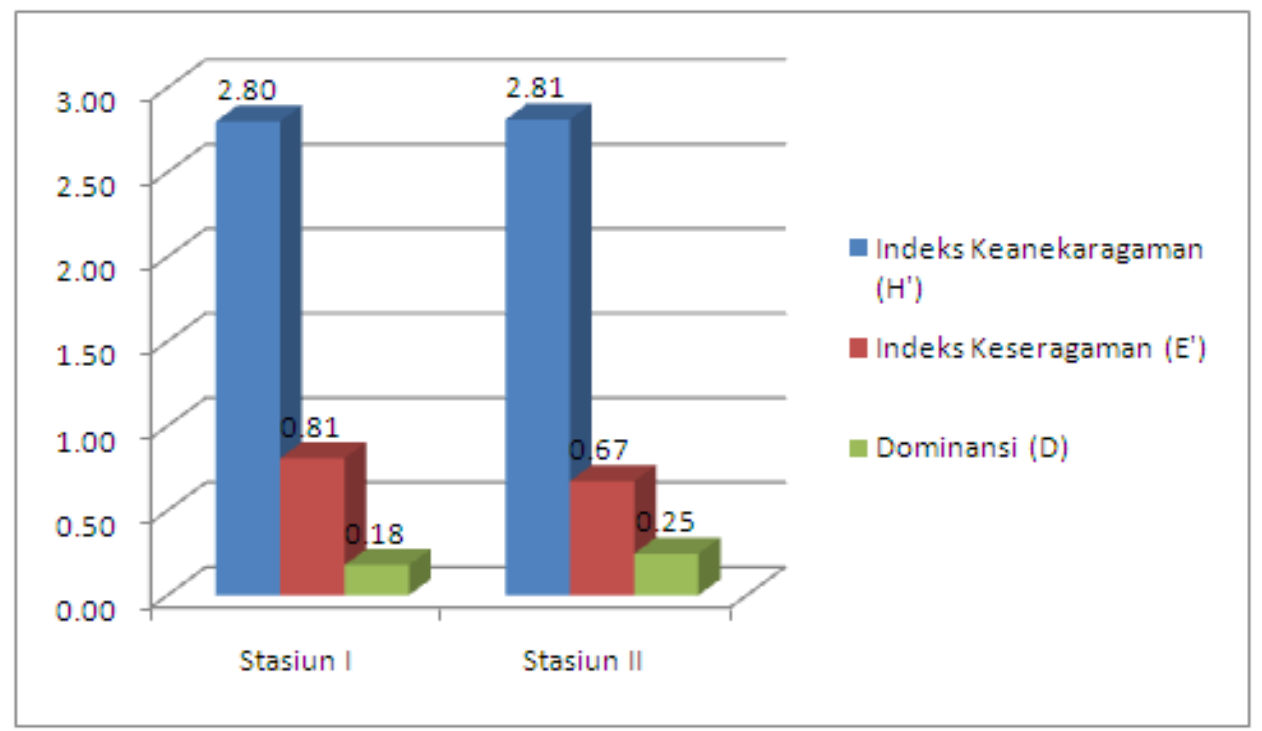

Gambar 4. Perbandingan Indeks H', Indeks E, dan Indeks D antara Stasiun I dan II

\section{Evaluasi Kualitas Lingkungan dengan Kurva ABC}

Analisis Kurva Abundance Biomass Comparison (ABC) dapat digunakan untuk mengetahui kondisi lingkungan dengan cara menganalisis jumlah total individu per satuan luas dan biomassa (berat kering) per satuan luas. Hasil Analisis Kurva ABC untuk Stasiun I dan II dapat dilihat pada Gambar 5.

Kurva ABC untuk Stasiun I menunjukkan kondisi perairan tidak terganggu karena kurva biomassa berada di atas kurva kepadatan. Meskipun pada Stasiun I jumlah jenis yang paling banyak ditemukan adalah jenis-jenis berukuran kecil dari Kelas Polychaeta, tetapi kepadatan dari masing-masing jenis hampir sama (hal ini juga dapat dilihat dari nilai Indeks $\mathrm{E}$ yang tinggi), namun ukuran dari jenis Telescopium telescopium (Kelas Gastropoda) cukup besar sehingga biomassanya besar. Tingginya nilai biomassa 
menyebabkan kumulatif dominan tinggi, dan nilai kumulatif dari kepadatan tidak ada yang melebihi biomassa pada rangkin yang sama (sehingga tidak terjadi tumpang tindih).

Jika dibandingkan antara Stasiun I dan II, hasil Analisis Kurva ABC yang didapat cederung sama, yaitu kondisi perairan tidak mengalami gangguan, hal tersebut ditandai dengan tidak adanya tumpang tindih antara kurva biomasa dengan kepadatan. Pada Stasiun II ditemukan jenis-jenis makrozoobentho dengan biomassa yang hampir keseluruhan cukup besar, hal tersebut menunjukkan kondisi pada Stasiun II masih banya nutrisi yang dibutuhkan makrozoobenthos.

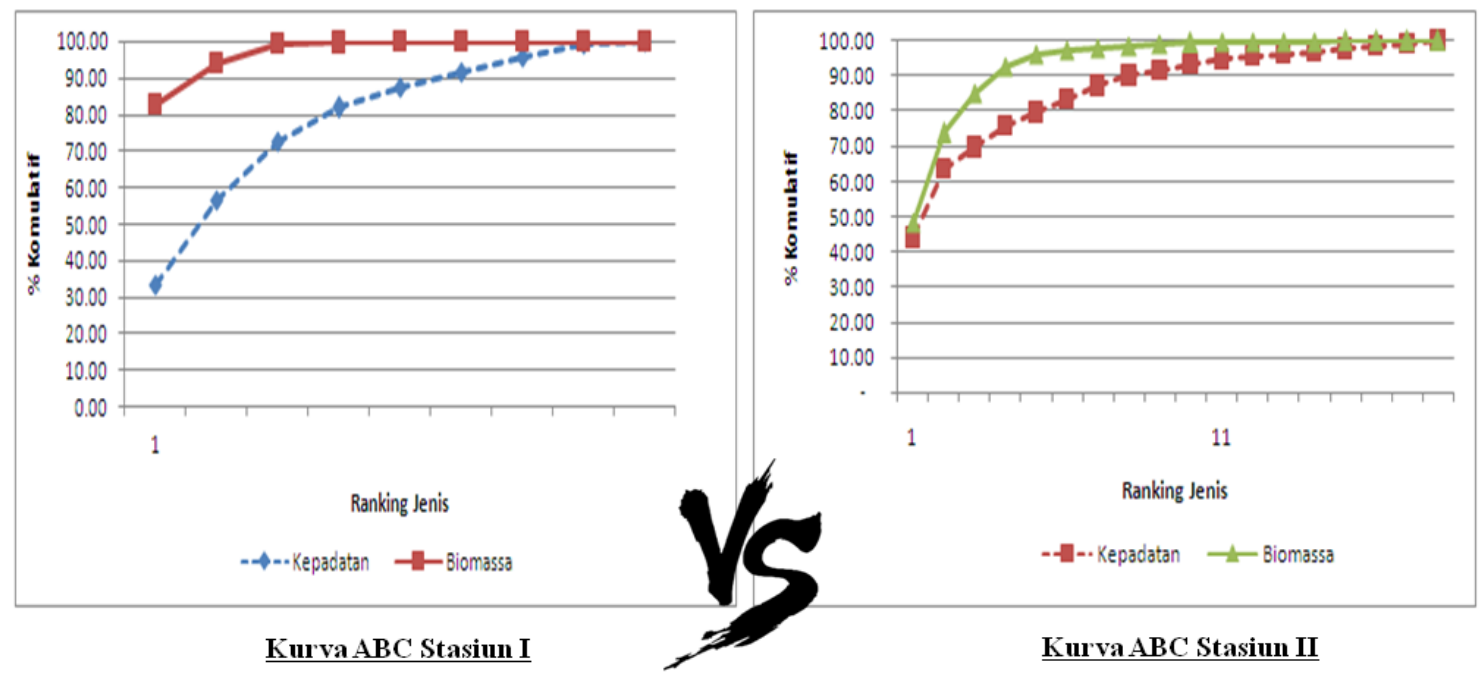

Gambar 5. Kurva ABC pada Stasiun I dan II

\section{$\underline{\text { Evaluasi Kualitas Air }}$}

Pada Tabel 1 di bawah disajikan hasil analisis laboratorium terhadap kualitas air di Stasiun I dan Stasiun II. Pada Tabel tersebut dapat dilihat bahwa dari seluruh parameter yang diamati, ada 3 parameter yang tidak memenuhi baku mutu, yaitu parameter Oksigen Terlarut (Dissolved Oxygen/DO) di Stasiun I dan II, parameter Kromium (Cr) di Stasiun II, serta parameter Tembaga $(\mathrm{Cu})$ di Stasiun I.

Nilai DO di Stasiun I adalah $0.73 \mathrm{mg} / \mathrm{l}$ dan di Stasiun II adalah $3.57 \mathrm{mg} / \mathrm{l}$ (baku mutu yang ditetapkan adalah $>5 \mathrm{mg} / \mathrm{l}$ ). Sangat rendahnya nilai DO di Stasiun I diduga disebabkan oleh banyaknya bahan organik yang masuk ke perairan tersebut (Stasiun I berlokasi di kawasan mangrove yang berdekatan dengan oulet pengolahan air lindi TPA Telaga Punggur). Di Stasiun II nilai DO lebih tinggi karena berada pada jarak $1 \mathrm{~km}$ dari TPA Telaga Punggur, namun nilainya tetap di bawah $5 \mathrm{mg} / \mathrm{l}$. 
Konsentrasi Cr di Stasiun II adalah $0.023 \mathrm{mg} / \mathrm{l}$ (sedangkan baku mutunya adalah $0.005 \mathrm{mg} / \mathrm{l})$. Menurut Mays (1996), kromium (Cr) termasuk unsur yang jarang ditemukan pada perairan alami. Kromium di perairan umumnya berasal dari limbah industri. Menurut Eckenfelder (1989), garam-garam kromium digunakan dalam indusri besi baja, cat, bahan pewarna/celupan (dyes), bahan peledak, tekstil, kertas, keramik, gelas, fotografi, sebagai penghambat korosi, dan sebagai campuran lumpur pengeboran (drilling mud). Di Stasiun I, konsentrasi $\mathrm{Cr}$ tidak terdeteksi, hal ini diprediksi karena logam $\mathrm{Cr}$ sudah mengalami pengikatan dengan senyawa lain dan mengendap di dasar perairan (sedangkan pengambilan sampel air dilakukan terhadap air permukaan). Hasil penelitian yang dilakukan oleh Waraney (2013) terhadap kandungan logam $\mathrm{Cr}$ pada jaringan tubuh gastropoda Telescopium telescopium diketahui bahwa Telescopium telescopium yang diambil dari Stasiun I rata-rata mengandung $\mathrm{Cr}$ sebanyak $78.72 \mathrm{mg} / \mathrm{kg}$, sedangkan Telescopium telescopium yang diambil dari Stasiun II rata-rata mengandung $\mathrm{Cr}$ sebanyak $24.86 \mathrm{mg} / \mathrm{kg}$.

Tingginya konsentrasi $\mathrm{Cu}$ di Stasiun I juga diprediksi dipengaruhi oleh buangan air limpasan dari TPA Telaga Punggur. Tembaga tidak termasuk senyawa beracun; namun konsumsi tembaga secara berlebih dapat terakumulasi pada hati, ginjal dan usus sehingga menimbulkan gangguan terhadap organ-organ tersebut (Bhattacharya, 1992). Tembaga banyak digunakan pada industri metalurgi, tekstil, elektronika, dan cat anti karat (Eckenfelder, 1989).

Tabel 1. Hasil Analisis Kualitas Air di Stasiun I dan Stasiun II

\begin{tabular}{|c|c|c|c|c|c|c|}
\hline \multirow{2}{*}{ Parameter } & \multirow{2}{*}{ Satuan } & \multirow{2}{*}{ Limit Deteksi } & \multicolumn{2}{|c|}{ Nilai di Stasiun } & \multirow{2}{*}{$\begin{array}{l}\text { Baku } \\
\text { Mutu }\end{array}$} & \multirow{2}{*}{$\begin{array}{c}\text { Alat/ } \\
\text { Metode *) }\end{array}$} \\
\hline & & & 1 & 2 & & \\
\hline \multicolumn{7}{|l|}{ INSITU } \\
\hline Suhu & ${ }^{\circ} \mathrm{C}$ & & 32.4 & 32.09 & $28-32$ & Termometer \\
\hline Salinitas & $\%$ & & 18 & 21 & s.d 34 & Refraktometer \\
\hline $\mathrm{pH}$ & & & 7.58 & 7.8 & $7.0-8.5$ & $\mathrm{pH}$ meter \\
\hline DO & $\mathrm{mg} / \mathrm{l}$ & & 0.73 & 3.57 & 5.0 & DO meter \\
\hline \multicolumn{7}{|l|}{ EKSITU } \\
\hline TSS & $\mathrm{mg} / \mathrm{l}$ & 8 & 20 & 27 & $20-80$ & $\begin{array}{l}\text { APHA, ed. 22, } \\
\text { 2012, 2540-D }\end{array}$ \\
\hline $\begin{array}{l}\text { Minyak \& } \\
\text { lemak }\end{array}$ & $\mathrm{mg} / \mathrm{l}$ & 1 & $<1$ & $<1$ & 1 & $\begin{array}{l}\text { APHA, ed. 22, } \\
2012,5520-B\end{array}$ \\
\hline $\begin{array}{l}\text { Raksa } \\
(\mathrm{Hg})\end{array}$ & $\mathrm{mg} / \mathrm{l}$ & 0.0002 & $\begin{array}{c}< \\
0.0002\end{array}$ & $\begin{array}{c}< \\
0.0002\end{array}$ & 0.001 & $\begin{array}{l}\text { APHA, ed. 22, } \\
2012,3112\end{array}$ \\
\hline
\end{tabular}




\begin{tabular}{|c|c|c|c|c|c|c|}
\hline \multirow{2}{*}{ Parameter } & \multirow{2}{*}{ Satuan } & \multirow{2}{*}{ Limit Deteksi } & \multicolumn{2}{|c|}{ Nilai di Stasiun } & \multirow{2}{*}{$\begin{array}{l}\text { Baku } \\
\text { Mutu }\end{array}$} & \multirow{2}{*}{$\begin{array}{c}\text { Alat/ } \\
\text { Metode } *)\end{array}$} \\
\hline & & & 1 & 2 & & \\
\hline $\begin{array}{l}\text { Kromium } \\
(\mathrm{Cr})\end{array}$ & $\mathrm{mg} / \mathrm{l}$ & 0.001 & $\begin{array}{c}< \\
0.001\end{array}$ & 0.023 & 0.005 & $\begin{array}{l}\text { APHA, ed. 22, } \\
2012,3110\end{array}$ \\
\hline $\begin{array}{l}\text { Arsen } \\
\text { (As) }\end{array}$ & $\mathrm{mg} / \mathrm{l}$ & 0.0002 & $\begin{array}{c}< \\
0.0002\end{array}$ & $\begin{array}{c}< \\
0.0002\end{array}$ & 0.012 & $\begin{array}{l}\text { APHA, ed. } 22, \\
2012,3110\end{array}$ \\
\hline $\begin{array}{l}\text { Kadmium } \\
(\mathrm{Cd})\end{array}$ & $\mathrm{mg} / \mathrm{l}$ & 0.001 & $\begin{array}{c}< \\
0.001\end{array}$ & $\begin{array}{c}< \\
0.001\end{array}$ & 0.001 & $\begin{array}{l}\text { APHA, ed. 22, } \\
2012,3110\end{array}$ \\
\hline $\begin{array}{l}\text { Timbal } \\
(\mathrm{Pb})\end{array}$ & $\mathrm{mg} / \mathrm{l}$ & 0.005 & $\begin{array}{c}< \\
0.005\end{array}$ & $\begin{array}{c}< \\
0.005\end{array}$ & 0.008 & $\begin{array}{l}\text { APHA, ed. 22, } \\
2012,3110\end{array}$ \\
\hline $\begin{array}{l}\text { Tembaga } \\
(\mathrm{Cu})\end{array}$ & $\mathrm{mg} / \mathrm{l}$ & 0.005 & 0.012 & $\begin{array}{c}< \\
0.005\end{array}$ & 0.008 & $\begin{array}{l}\text { APHA, ed. 22, } \\
2012,3110\end{array}$ \\
\hline Seng (Zn) & $\mathrm{mg} / \mathrm{l}$ & 0.005 & 0.005 & $\begin{array}{c}< \\
0.005\end{array}$ & 0.05 & $\begin{array}{l}\text { APHA, ed. 22, } \\
2012,3110\end{array}$ \\
\hline
\end{tabular}

Uji Mann-Whitney untuk Membandingkan Jumlah Jenis Makrozoobenthos antara Dua Stasiun

Uji Mann-Whitney merupakan alternatif bagi Uji $t$ (pengujian untuk membandingkan mean dari 2 populasi). Uji Mann Whitney merupakan uji non-parametrik yang digunakan apabila data sampel yang ada tidak terdistribusi normal. Dalam hal ini Uji Mann-Whitney digunakan untuk membandingkan jumlah jenis makrozoobenthos antara 2 stasiun. Berdasarkan hasil Uji Mann-Whitney didapatkan bahwa P-Value adalah sebesar 0.3123; dengan toleransi kesalahan 5\% (atau 0.005), maka dapat disimpulkan bahwa jumlah jenis makrozoobenthos di Stasiun I dan Stasiun II adalah sama (P-Value $\left.>\alpha_{0.05}\right)$.

\section{Uji t untuk Membandingkan Kepadatan dan Keanekaragaman Makrozoo-benthos antara Dua Stasiun}

Uji t digunakan untuk membandingkan mean dari 2 populasi apabila data sampel terdistribusi normal, dalam hal ini Uji t digunakan untuk membandingkan 2 hal, yaitu kepadatan dan keanekaragaman makrozoobenthos antara dua stasiun pengamatan. Untuk variabel kepadatan makrozobenthos, didapatkan $t_{\text {hitung }}$ sebesar 0.68 sedangkan $t_{\text {tabel-nya }}$ $\left(\alpha_{0.05}\right)$ pada adalah 2.446, karena $t_{\text {hitung }}<t_{\text {tabel }}$ maka dapat disimpulkan bahwa kepadatan jenis makrozobenthos pada Stasiun I dan II adalah sama. Untuk variabel keanekaragaman makrozobenthos, didapatkan $t_{\text {hitung }}$ sebesar 1.95 sedangkan $t_{\text {tabel}}$-nya $\left(\alpha_{0.05}\right)$ pada adalah 2.446, karena $t_{\text {hitung }}<t_{\text {tabel }}$ maka dapat disimpulkan juga bahwa keanekaragaman jenis makrozobenthos pada Stasiun I dan II adalah sama. 


\section{KESIMPULAN}

Stasiun I makrozoobenthos didominasi oleh Kelas Olygochaeta Famili Tubificidae yang bersifat toleran, yang menunjukan adanya pencemaran organik. Sedangkan pada Stasiun II makrozoobenthos didominasi oleh Kelas Gastropoda yang bersifat fakultatif. Nilai Indeks H', E, dan D antara Stasiun I dan II tidak berbeda jauh. Nilai Indeks H berada pada kategori sedang yang menunjukkan perairan tercemar ringan. Nilai Indkes E tergolong tinggi yang menunjukkan bahwa tidak ada ada jenis makrozoobenthos yang mendominasi, hal tersebut juga didukung dengan rendahnya nilai Indeks D.

Analisis Kurva ABC menunjukkan bahwa kondisi perairan Stasiun I dan II belum terganggu. Dari keseluruhan parameter kualitas air yang diamati, ada 3 parameter yang tidak memenuhi baku mutu, yaitu DO, Cr, dan Cu. Berdasarkan hasil Uji Mann-Whitney diketahui bahwa jumlah jenis makrozoobenthos di Stasiun I dan II tidak berbeda signifikan. Berdasarkan hasil Uji t diketahui bahwa kepadatan jenis dan keanekaragaman jenis makrozoobenthos di Stasiun I dan II tidak berbeda signifikan.

\section{REFERENSI}

Barnes, R. D., W.F. Walker, and C.A Ville. 1999. Zoologi Umum Edisi 6 (Terjemahan). Erlangga.

Barus, T. A. 2002. Limnologi. FMIPA USU. Medan.

Bhattacharya, S. K. 1992. Urban domestic water supply in developing countries. CBS Publishers \& Distributors. New Delhi.

Eckenfelder, W. W. 1989. Industrial Water Pollution Control. McGraw-Hill, Inc. New York.

Fachrul, M. F. 2007. Metode Sampling Bioekologi. Penerbit Bumi Aksara. Jakarta.

Fiene-Severns, P., M. Severns, and R. Dyerly. 2000. Periplus Narute Guides Tropical Seashells. Periplus Edition (HK) Ltd. Singapore.

Fitriana, Y. R. 2006. Keanekaragaman dan Kemelimpahan Makrozoobenthos di Hutan Mangrove Hasil Rehabilitasi Taman Hutan Raya Ngurah Rai Bali dalam Jurnal Biodiversitas Vol. 7 No. 1. Jurusan Biologi FMIPA. Universitas Sebelas Maret Surakarta. Solo. 
Jailani dan M. Nur. 2002. Studi Biodiversiti Bentos di Krueng Daroy Kacamatan Darus Imarah Kabupaten Aceh Besar dalam Jurnal Biodiversitas Vol. 3 No. 1. Jurusan Biologi FMIPA. Universitas Sebelas Maret Surakarta. Solo.

Mays, L. W. 1996. Water Resources Handbook. McGraw-Hill. New York.

Sabelli, B. 1991. The Mac Donald Encyclopedia of Shells. Mac Donald \& Co. Publisher Ltd. London.

Suwignyo, S. B. Widigdo, Y. Wardiatno, dan M. Krisanti. 2005. Avertebrata Air Jilid 1. Penebar Swadaya. Jakarta.

Suwignyo, S. B. Widigdo, Y. Wardiatno, dan M. Krisanti. 2005. Avertebrata Air Jilid 2. Penebar Swadaya. Jakarta.

Waraney, A. 2013. Kelimpahan Populasi dan Perbedaan Morfometrik Telescopium telescopium pada Habitat Mangrove di Sungai Bongkok Kampung Bagan Tanjung Piayu dan Sekitar TPA Telaga Punggur Kota Batam (Skripsi). Program Studi Pendidikan Biologi FKIP Universitas Riau Kepulauan. Batam

Warwick, R.M. 1986. A New Method of Detecting Pollution Effects on Marine Macrobenthic Communities in Marine Biology Journal Vol. 92. Springer-Verlag. London. 